\title{
RELATIONSHIP BETWEEN C-REACTIVE PROTEIN TO ALBUMIN RATIO AND THE EXTENT OF CORONARY ARTERY DISEASE SEVERITY IN PATIENTS WITH NON ST ELEVATED MYOCARDIAL INFARCTION
}

\author{
By \\ Hamdy Saleh Abd El-Moaty, Mohammed Hesham Hassan Ezzat, Abd \\ El-Aleem Abd El-Aleem Ali El-Guindy* and Ahmed Abd El-Raouf \\ Mahdy \\ Departments of Cardiology and Clinical Pathology*, Faculty of Medicine, Al-Azhar \\ University
}

Corresponding author: Hamdy Saleh Abd El-Moaty,

E-mail: hamdysaleh9010@gmail.com

\begin{abstract}
Background: Coronary artery diseases (CAD) are as atherosclerotic heart disease, atherosclerotic cardiovascular diseases, coronary heart diseases (CHD), or ischemic heart disease (IHD). CAD is the largest contributor of cardiovascular diseases (CVDs), and mortality rate is due in prevalence to atherosclerosis, a chronic inflammatory condition of the arterial wall.

Objective: To assess the relationship between $\mathrm{C}$ reactive protein /albumin ratio and the extent of coronary coronary disease assessed by the syntax score I in patients with non ST elevated myocardial infarction.

Patients and methods: This was a prospective cohort study carried out at Cardiology Department of AlAzhar University, and Al-Agouza Cardiology Department, and enrolled 100 patients admitted with non STelevation myocardial infarction and underwent coronary intervention during the period from January 2019 to February 2020.

Results: There was a non-statistically significant relation regarding gender and age. There was statistically significant relation regarding diabetes mellitus (DM) and dyslipidemia (cholesterol and LDL). There was also a statistically significant relation regarding syntax score, CRP and also CRP/Alb ratio.

Conclusion: There was a correlation between CRP/ Albumin ratio and the severity of coronary artery disease assessed by syntax score I.
\end{abstract}

Keywords: C-reactive protein, Albumin Ratio, Coronary Artery Disease, Non ST elevated myocardial infarction

INTRODUCTION

Non-ST-segment elevation myocardial infarction (NSTEMI) remains the leading causes of death in individuals with coronary artery disease (Yeh et al., 2010).
Coronary artery disease severity is closely related to mortality, and the Synergy between Percutaneous Coronary Intervention with TAXus and cardiac surgery (SYNTAX) score (SS), the most 
commonly used scoring system for determining CAD severity (Farooq et al., 2013).

The developed SS II, designed by adding clinical variables identified by applying a Cox proportional hazards model to the results of the SYNTAX trial, provides greater prognostic accuracy in clinical settings for patients with CAD and acute myocardial infarction (Magro et al., 2011).

Identifying the factors associated with intermediate-high SS and high SS II may improve the prognosis of patients with NSTEMI by enabling early referral for timely coronary angiography and revascularization, as well as close monitoring during hospital stay and after discharge. Inflammation plays a major role in the progression and destabilization of atherosclerotic plaque (Karadeniz et al., 2015).

The relationship between CRP, SS, and CAD severity were determined in previous studies. Inflammation plays an important role in all stages of atherosclerosis. They are markers of inflammation that are frequently used in clinical practice (Çăgdaş et al., 2017).

Decreased albumin level may be associated with increased risk of morbidity and mortality in a range of cardiovascular diseases. Kurtul and colleagues (2016) demonstrated that decreased albumin level is an independent predictor of high SS and in-hospital mortality in patients with acute coronary syndrome.

The inflammatory status can be measured using acute phase reactants (APRs). The commonly used parameters,
C-reactive protein (CRP) and albumin, known as positive and negative APRs, respectively, are associated with the presence of CAD, CAD severity (Taniguchi et al., 2010).

CRP to albumin ratio (CAR) is believed to be more accurate indicator of the inflammatory status than CRP or albumin alone. Furthermore, high CAR was associated with worse prognosis in patients with critical illness and malignancy (Fairclough et al., 2010).

The aim of the present study was to evaluate the possible relationship of coronary artery disease severity (identified using the syntax score I) and C-reactive protein to albumin ratio.

\section{PATIENTS AND METHODS}

This prospective cohort study was carried out at cardiology department of Al AGouza hospital and Al-Hussein Hospital at the period from January 2019 to February 2020.

This study included one hundred (100) patients who admitted to Al- Agouza Hospital and Al-Hussein hospital with clinical features of non ST- elevation myocardial infarction and undergone coronary intervention.

Inclusion criteria: All patients with nonST segment elevation myocardial infarction.

Exclusion criteria: Patients with a history of previous coronary artery disease treated with percutaneous coronary intervention or coronary artery bypass grafting, e.g. malignancy, active infection, connective tissue disorder, patient with Chronic kidney disease, and patient with hepatic disease. 


\section{All patients subjected to the following:}

\section{A. Full history taking: with special emphasis on:}

1. Demographic criteria including Age, sex.

2. A detailed medical and cardiac history including cardiovascular risk factors: History of smoking, hypertension diagnosed and /or treated with medications, diet and/or exercise, diabetes Mellitus, dyslipidemia, and family history of ischemic heart disease or sudden cardiac death.

\section{B. General and local examination:} Pulse, blood pressure, neck veins, edema of lower limbs, chest and abdominal examination, and cardiac examination including inspection, palpation and auscultation.

\section{Laboratory investigations:}

1. Serum creatinine and blood urea: detected by Cobas 6000 C501 electro chemiluminescent assay before and after (from 12 to 48 hours) coronary intervention.

2. Complete blood cell count using Sysmex S. F3000 automated analyzer.

3. Random blood sugar level.

4. Lipid profile: This included total cholesterol, low-density lipoproteins, high-density lipoproteins, and triglycerides using Cobas Integra instrument - spectrophotometry method serum albumin.

5. Reactive protein (CRP ELISA Kit 5/11 Catalog Number: CRP31- K01, USA).
6. C-reactive protein to albumin ratio: The albumin and CRP levels will be measured. The CAR will be calculated as the ratio of CRP to the albumin level.

D. Resting surface 12 ECG leads: Surface ECG was done on admission at a paper speed of $25 \mathrm{~mm} / \mathrm{s}$ and amplification of $10 \mathrm{~mm} / \mathrm{mv}$. Depicted ECG changes were either, ST depression $>0.5 \mathrm{~mm}$ in 2 contiguous leads, $\mathrm{T}$ wave inversion or normal ECG (no ST deviation).

E. Transthoracic Echo Doppler study: Detailed transthoracic echocardiography was performed to all patients using GE Vivid 9. The conventional Echo was performed by experienced echo cardiographer in accordance with the recommendations of the American Society of Echocardiography (ASE) and European Association of Echocardiography (EAE). The mean of three measurements was used in the analysis. The echocardiogram was performed with the patient breathing quietly and lying in the left lateral position.

F. Coronary angiography: Approach either femoral or radial if available, and assessment if lesion in 2 orthogonal views.

\section{G. Calculating syntax score.}

\section{Statistical analysis:}

Statistical presentation and analysis of the present study was conducted, using the mean, standard deviation, student t- test, Linear Correlation Coefficient and Analysis of variance [ANOVA] tests by SPSS V20. Quantitive data are presented 
as mean, slandered deviation and range and were compared by Mann-Whitney test. Quantitive data are presented as number and frequency. $\mathrm{P}<0.05$ was considered significant.

\section{RESULTS}

The mean age of the study group was $54.520 \pm 7.889$ years and 37 patients $(37 \%)$ were females. In our study population, 28 patients $(28 \%)$ were suffering from diabetes mellitus (all type II), 39(39\%) had arterial hypertension, and 64 (64\%) were smokers. The mean body mass index (BMI) of the study group was $28.010 \pm 2.545 \mathrm{~kg} / \mathrm{m} 2$. In our study, there were $28 \%$ diabetic patients, 39\% hypertensive patients, $64 \%$ smoking and $62 \%$ dyslipidemia patient (Table 1).

Table (1): Basic demographic data and risk factors

\begin{tabular}{|c|c|c|c|}
\hline \multicolumn{2}{|c|}{ Demographic Data } & $\mathbf{N}$ & $\%$ \\
\hline \multirow{2}{*}{ Sex } & Male & 63 & 63.00 \\
\hline & Female & 37 & 37.00 \\
\hline \multirow{2}{*}{ Age } & Range & \multicolumn{2}{|c|}{$40-68$} \\
\hline & Mean \pm SD & \multicolumn{2}{|c|}{$54.520 \pm 7.889$} \\
\hline \multirow{2}{*}{ Height } & Range & \multicolumn{2}{|c|}{$167-183$} \\
\hline & Mean \pm SD & \multicolumn{2}{|c|}{$175.790 \pm 4.812$} \\
\hline \multirow{2}{*}{ Weight } & Range & \multicolumn{2}{|c|}{$70-97$} \\
\hline & Mean \pm SD & \multicolumn{2}{|c|}{$86.240 \pm 8.115$} \\
\hline \multirow{2}{*}{ BMI } & Range & \multicolumn{2}{|c|}{$20-33$} \\
\hline & Mean \pm SD & \multicolumn{2}{|c|}{$28.010 \pm 2.545$} \\
\hline \multicolumn{2}{|c|}{ Risk Factors } & & \\
\hline \multirow{2}{*}{ HTN } & Yes & 39 & 39.00 \\
\hline & No & 61 & 61.00 \\
\hline \multirow{2}{*}{ Dyslipidemia } & Yes & 62 & 62.00 \\
\hline & No & 38 & 38.00 \\
\hline \multirow{2}{*}{ DM } & Yes & 28 & 28.00 \\
\hline & No & 72 & 72.00 \\
\hline \multirow{2}{*}{ Smoking } & Yes & 64 & 64.00 \\
\hline & No & 36 & 36.00 \\
\hline
\end{tabular}

ECG criteria on examination

Sixty four patients (64\%) had ECG changes in the form of 14 patients ST segment depression, 50 patients inverted $\mathrm{T}$ wave (Figure 1). 


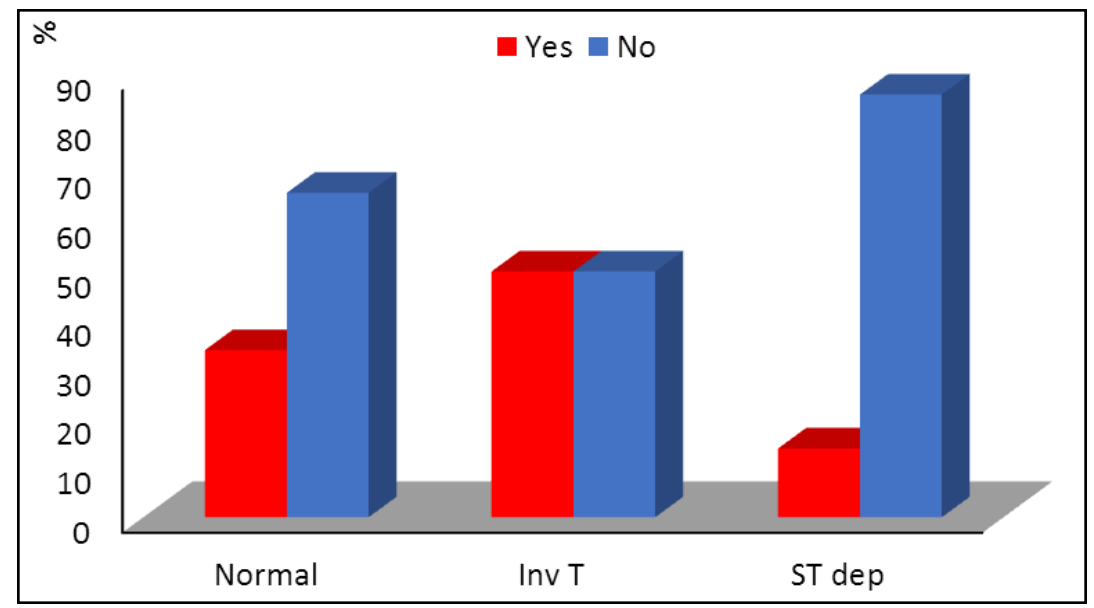

Figure (1): ECG criteria on examination.

According to SYNTAX I score of severity of coronary artery disease, there were 40 (40) single vessel disease. There were $9(9 \%)$ patients two vessel disease. There were $44(44 \%)$ patients three vessel disease. There were 7 (7\%) patients with four vessel disease.

Echocardiographic data on examination: Mean left ventricular ejection fraction (EF) was $53.090 \pm 15.792 \%$. According to LVEF, patients with LVEF (>50\%) was noticed in 61 patients $61 \%$, with midrange LVEF (40-49\%) noticed in 10 patients (10\%), and patients with heart failure with reduced LVEF $(<40 \%)$ noticed in 29 patients (29\%). No RSWMA was observed in 76 patients (76\%) (Table 2).

Table (2): Coronary angiographic data and echocardiography data regarding RWMA, EF

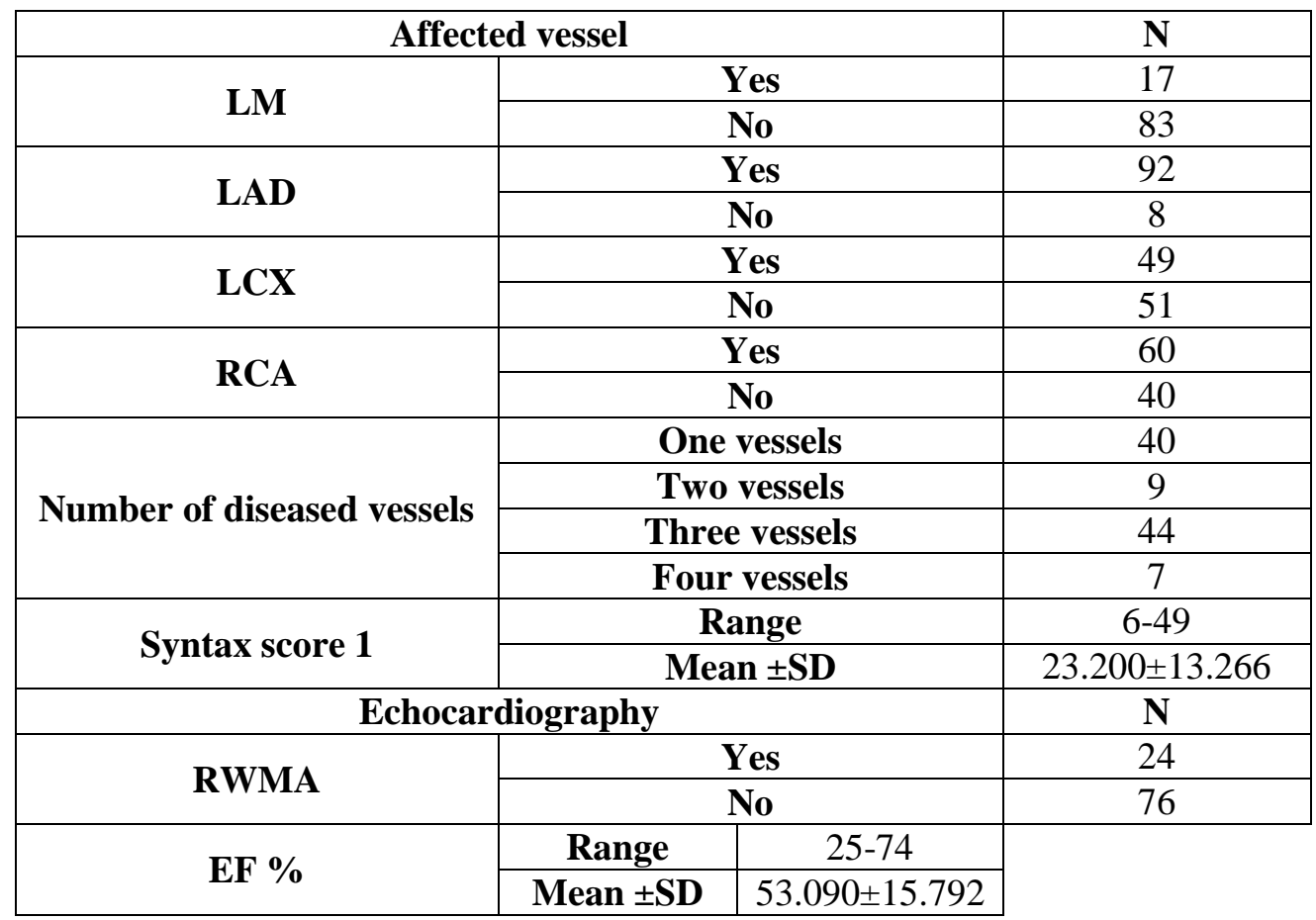

RWMA: regional wall motion abnormality, LVEF: left ventricular ejection fraction. 
There were no significant relations between CAR ratio and hypertension ( $\mathrm{P}$ value 0.157 ), smoking (p-value 0.764 ), but there were significant relations between CAR and DM (P value .002), Dyslipidemia (p-value .001). There was a significant relation between CAR ratio and ST depression ECG finding (P value .005). There was no significant relation between CAR ratio and RWMA. There was no significant relation between CAR ratio and Number of diseased vessels (Table 3).

Table (3): Correlation between CAR ratio and risk factors, ECG findings, and RWMA and Number of diseased vessels in our study group

\begin{tabular}{|c|c|c|c|c|}
\hline \multicolumn{2}{|c|}{$\begin{array}{ll}\text { Parameters } & \text { CAR } \\
\end{array}$} & $\mathbf{N}$ & Median (IQR) & Mann-Whitney Test \\
\hline \multicolumn{5}{|c|}{ Risk Factors: } \\
\hline \multirow{2}{*}{ HTN } & Yes & 39 & $2.6(1.4-5)$ & \multirow{2}{*}{0.924} \\
\hline & No & 61 & $2.5(1.58-4.75)$ & \\
\hline \multirow{2}{*}{ Dyslipidemia } & Yes & 62 & $3.3(1.6-5.375)$ & \multirow{2}{*}{$0.005^{*}$} \\
\hline & No & 38 & $1.85(1.4-3.15)$ & \\
\hline \multirow{2}{*}{ DM } & Yes & 28 & $3.1(1.6-8.875)$ & \multirow{2}{*}{$0.043 *$} \\
\hline & No & 72 & $2(1.515-4)$ & \\
\hline \multirow{2}{*}{ Smoking } & Yes & 64 & $2(1.56-5)$ & \multirow{2}{*}{0.634} \\
\hline & No & 36 & $3.1(1.625-4.875)$ & \\
\hline \multicolumn{5}{|l|}{ ECG: } \\
\hline \multirow{2}{*}{ Normal } & Yes & 34 & $3.2(1.52-5)$ & \multirow{2}{*}{0.564} \\
\hline & No & 66 & $2(1.56-4.25)$ & \\
\hline \multirow{2}{*}{$\operatorname{Inv} \mathbf{T}$} & Yes & 50 & $2(1.56-4.25)$ & \multirow{2}{*}{0.402} \\
\hline & No & 50 & $2.85(1.59-5)$ & \\
\hline \multirow{2}{*}{ ST dep } & Yes & 14 & $3.1(1.9-3.625)$ & \multirow{2}{*}{0.485} \\
\hline & No & 86 & $2(1.56-5)$ & \\
\hline \multirow{2}{*}{$\begin{array}{c}\text { Echocardiography } \\
\text { RWMA }\end{array}$} & Yes & 24 & $3.3(1.57-5)$ & \multirow{2}{*}{0.240} \\
\hline & No & 76 & $2(1.56-4.375)$ & \\
\hline & & & & Kruskal-Wallis Test \\
\hline \multirow{4}{*}{$\begin{array}{c}\text { Number of } \\
\text { diseased vessels }\end{array}$} & One vessels & 40 & $1.95(1.4-4.725)$ & \multirow{4}{*}{0.097} \\
\hline & Two vessels & 9 & $4(2.85-8.5)$ & \\
\hline & Three vessels & 44 & $2(1.56-5)$ & \\
\hline & Four vessels & 7 & $3.1(1.9-3.1)$ & \\
\hline
\end{tabular}


There was a significant relation between CAR ratio and severity of SYNTAX score I, cholesterol and LDL with significant $\mathrm{P}$ value $=0.003,0.001$ and 0.001 respectively. There was a strong positive linear relationship between CAR ratio and Severity of coronary artery disease assessed by SYNTAX I score (Table 4).

Table (4): Correlation between CAR ratio and severity of SYNTAX I score \& Labs.

\begin{tabular}{|l|c|c|}
\hline Correlations & CAR & P-value \\
\hline Syntax score 1 & 0.214 & 0.003 \\
\hline Age & -0.019 & 0.851 \\
\hline Height & 0.116 & 0.252 \\
\hline Weight & 0.098 & 0.332 \\
\hline BMI & -0.067 & 0.506 \\
\hline Echocardiography EF \% & -0.437 & $<0.001$ \\
\hline LAB CRP & 0.667 & $<0.001$ \\
\hline LAB Albumin & 0.115 & 0.256 \\
\hline TG & 0.901 & $<0.001$ \\
\hline Cholesterol & 0.880 & $<0.001$ \\
\hline HDL & -0.879 & $<0.001$ \\
\hline LDL & 0.910 & $<0.001$ \\
\hline
\end{tabular}

\section{DISCUSSION}

Among individuals with an acute phase of CAD, serum albumin is also reported as a strong prognostic factor Hartopo et al. (2014) evaluated small number patients with acute coronary syndrome (ACS) from a single center. Hypoalbuminemia $(<3.5 \mathrm{~g} / \mathrm{dL})$ measured upon admission was associated with in hospital adverse events, including death, acute heart failure, cardiogenic shock, and reinfarction.

In our study, as regarding the age, the mean age was $54.520 \pm 7.889$ years with non-statistically significant. Regarding gender, there were $63 \%$ males and $37 \%$ females with non-statistically significant difference between the two groups. Yahagi et al. (2015) stated that most of the underlying systemic risk factors for coronary artery disease are similar between men and women. However, the impact of various risk factors is different between men and women, with smoking being a stronger risk in women than men, especially in younger women. Furthermore, the influence of the menopause is also unique and important in women: incidence of plaque rupture is higher in older women as compared to younger.

Our results showed a statistically significant relation as regarding DM and dyslipidemia (cholesterol, LDL-C) and non-significant difference with the other risk factors. Presence of DM, elevated values of cholesterol, LDL-C and CAR were found to be independent predictors of high SS (Caixeta et al., 2014).

In our study as regarding serum cholesterol, the mean was $174.300 \pm 34.157 \quad$ with statistically significant. For Serum LDL, the mean was $108.260 \pm 19.461 \quad$ with statistically significant. Our results were concordant 
with Suzuki et al. (2019), who stated that there was a statistical significant relation as regarding total cholesterol and LDL, with non-significant difference as regard HDL.

Our results showed that Syntax Score, the mean was $23.200 \pm 13.266$, and for $\mathrm{CRP}$, the mean was $12.473 \pm 9.448$ with statistically significant differences.

We also showed significant correlation between CRP/ ratio, CRP, Albumin and syntax score / Albumin ratio and CRP while non-significant correlation with Albumin.

Kurtul et al. (2016) assumed that increased CRP/albumin ratio indicates a higher inflammatory state and may be superior to CRP and albumin alone in determining the prevalence and severity of CAD. They also stated that elevated CAR levels in CAD patients were independent predictors of intermediate-high SS group, and the predictive accuracy of CAR was better than CRP and albumin level, as per the comparison of the ROC curves.

Oh et al. (2017) stated that the relationships between albumin, CRP level, and SS were similar to that reported in previous trials. Merging albumin and CRP into a single index demonstrated to be associated with poor prognosis in a variety of disorders including cancer and sepsis.

The inflammatory status, reflected by the decreased albumin level, increased CRP level, and higher CAR, were closely related to severe $\mathrm{CAD}$, which was determined using the SS. The CAR was found to be a more accurate predictor of intermediate-high SS than CRP or albumin (Çăgdaş et al., 2017).

\section{CONCLUSION}

There was a correlation between CRP/ Albumin ratio and the severity of coronary artery disease assessed by syntax score I.

\section{REFERENCES}

1. Çağdaş M, Rencüzoğullari I, Karakoyun $S$, Karabağ Y, Mahmut Y, Inanç A, Doğan I, Öznur S, Çağdaş A, Hayriye T and Halil I. (2017): Assessment of Relationship Between C-Reactive Protein to Albumin Ratio and Coronary Artery Disease Severity in Patients With Acute Coronary Syndrome. J Clin Lab Anal., 32(7):224-230.

2. Caixeta A, Généreux $P$, Palmerini $T$, Lansky AJ, Mehran R, Dangas GD, Xu K, Brener SJ and Stone GW. (2014): Prognostic utility of the SYNTAX score in patients with single versus multivessel disease undergoing percutaneous coronary intervention (from the Acute Catheterization and Urgent Intervention Triage StrategY [ACUITY] trial). Am J Cardiol., 113:203-210.

3. Fairclough $E$, Cairns $E$, Hamilton $J$ and Kelly C. (2010): Evaluation of a modified early warning system for acute medical admissions and comparison with C-reactive protein/albumin ratio as a predictor of patient outcome. Clin Med., 9(1):30-3.

4. Farooq V, van Klaveren D, Steyerberg EW, Meliga E, Vergouwe Y, Chieffo A, Kappetein AP, Colombo A, Holmes DR Jr, Mack M, Feldman T, Morice MC, Ståhle E, Onuma Y, Morel MA, Garcia-Garcia HM, van Es GA, Dawkins KD, Mohr FW and Serruys PW. (2013): Anatomical and clinical characteristics to guide decision making between coronary artery bypass surgery and percutaneous coronary intervention for individual patients: development and validation of SYNTAX score II. Lancet, 381(9867):639-50.

5. Hartopo AB, Gharini PP and Setianto BY. (2014): Low serum albumin levels and inhospital adverse outcomes in acute coronary syndrome. Int Heart J., 51(4):221-6.

6. Karadeniz M, Duran M, Akyel A, Yarlıglues M, Ocek AH and Elik IE. 
(2015): High sensitive CRP level is associated with intermediate and high SYNTAX score in patients with acute coronary syndrome. Int Heart J., 56(4):377-80.

7. Kurtul A, Murat SN, Yarlioglues M, Duran M, Ocek AH, Koseoglu C and Aksoy O. (2016): Usefulness of serum albumin concentration to predict high coronary SYNTAX score and in-hospital mortality in patients with acute coronary syndrome. Angiology, 67(1): 34-40.

8. Magro M, Nauta S and Simsek C. (2011): Value of the SYNTAX score in patients treated by primary percutaneous coronary intervention for acute ST-elevation myocardial infarction: the MI SYNTAX score study. Am Heart J., 161(4): 771-81.

9. Oh J, Kim SH, Park KN, Oh SH, Kim YM, Kim HJ and Youn CS. (2017): Highsensitivity $\mathrm{C}$-reactive protein/albumin ratio as a predictor of in-hospital mortality in older adults admitted to the emergency department. Clinical and Experimental Emergency Medicine, 4: 19-24.
10. Suzuki S, Hashizume N, Kanzaki Y, Maruyama T, Kozuka A and Yahikozawa K. (2019): Prognostic significance of serum albumin in patients with stable coronary artery disease treated by percutaneous coronary intervention. PloS One, 14: 219044-219048.

11. Taniguchi H, Momiyama Y, Ohmori R, Yonemura A, Yamashita T, Tamai $S$, Nakamura $H$ and Ohsuzu F. (2010): Associations of plasma C-reactive protein levels with the presence and extent of coronary stenosis in patients with stable coronary artery disease. Atherosclerosis, 178(1):173-7.

12. Yahagi $K$, Davis $H R$, Arbustini $E$ and Virmani RJA. (2015): Sex differences in coronary artery disease: pathological observations. Atherosclerosis, 239: 260-267.

13. Yeh RW, Sidney S, Chandra M, Sorel M, Selby JV and Go AS. (2010): Population trends in the incidence and outcomes of acute myocardial infarction. N Engl J Med., 362(23):2155-65. 


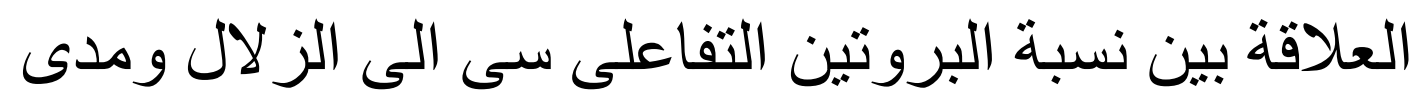

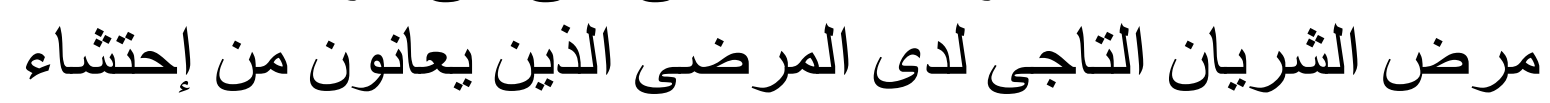

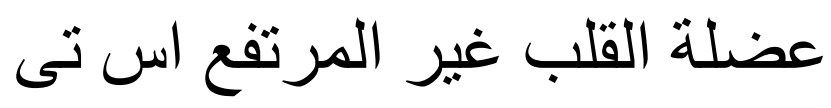

حمدى صالح عبد المعطى، محمد هشام حسن عزت، عبد العليم عبد العليم على

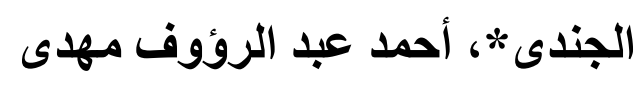

قسمي القلب والأوعية الاموية و الباثولوجيا الاكلينيكية*، كلية الطب، جامعة الأزهر

E-mail: hamdysaleh9010@gmail.com

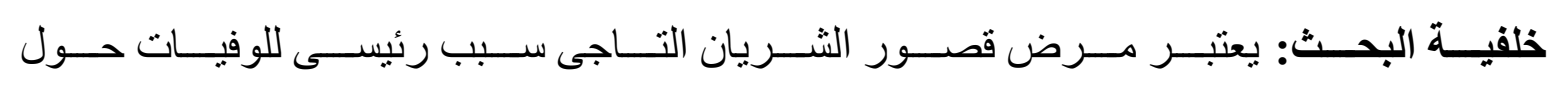

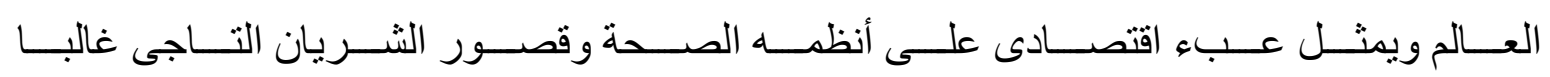

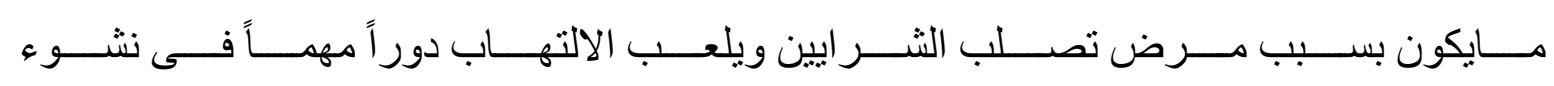

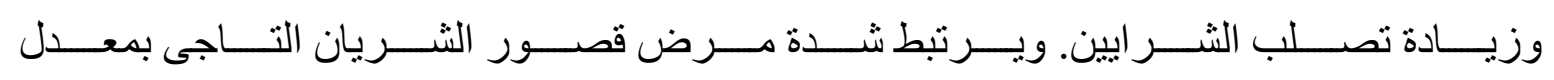

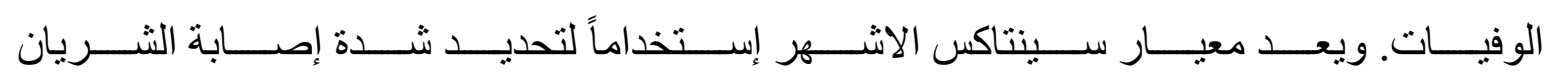

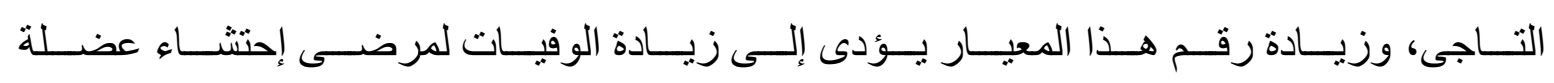
القلب الغير مرتفع الاس تى. وزئ

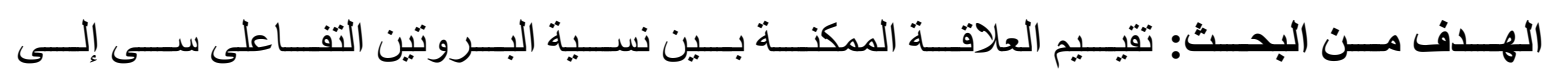

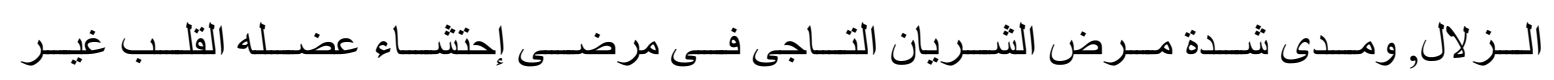
مرتفع الاس تى.

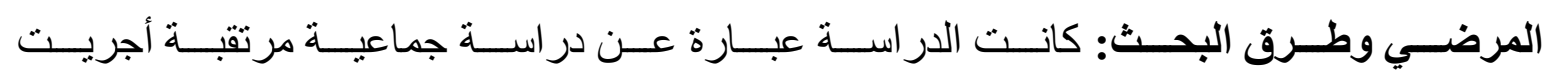

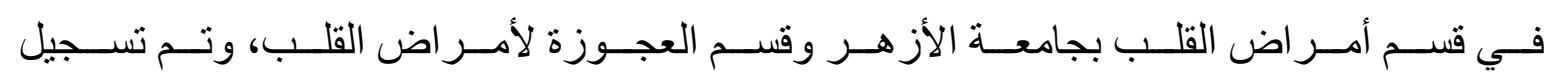

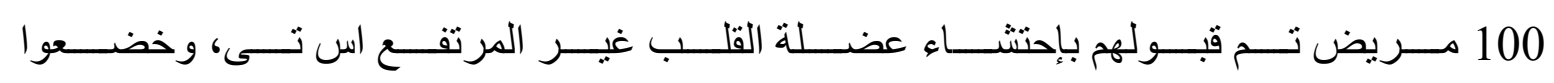

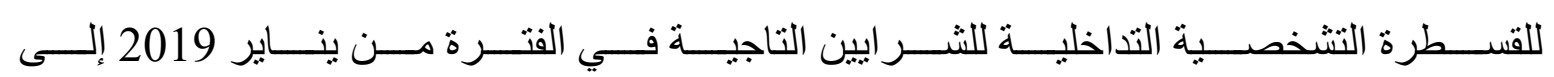
فبر اير 2020.

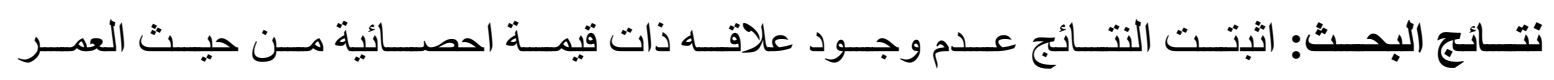

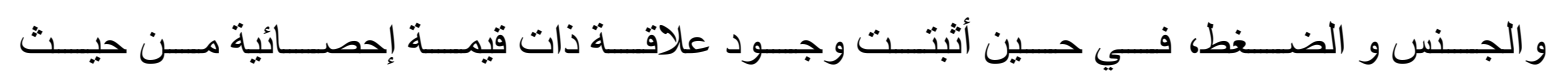


RELATIONSHIP BETWEEN C-REACTIVE PROTEIN TO ALBUMIN... 3213

الســـكر و الكوليســترول. أثبتـــت الدر اســـة وجــود علاقــة ذات قيمـــة إحصـــائية بــين نســبة البروتين التفاعلى سي إلى الز لال ومدى مرض الثريان التاجى.

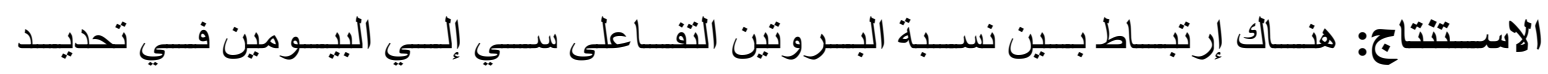
درجة إعتلال الثريان التاجى.

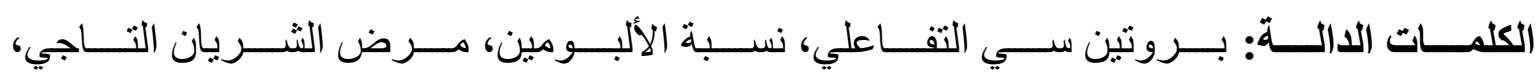
إحتثاء عضلة القلب غير المرتفع اس تى. 